\title{
La carga viral fue el principal predictor del riesgo de transmisión heterosexual de VIH
}

Viral load and heterosexual transmission of human immunodeficiency virus type 1. Rakai Project Study Group. Quinn TC, Wawer MJ, Sewankambo N, y col. New Engl J Med.2000;342:921-29.

\section{Objetivo}

Evaluar la influencia de la carga viral y otros parámetros clínicos en la transmisión heterosexual del virus de inmunodeficiencia humano tipo $1(\mathrm{VIH})$.

\section{Diseño}

Estudio de cohorte prospectiva* con 22.5 meses de seguimiento.

\section{Lugar}

Comunidad rural de Uganda (prevalencia de infección por VIH $=16,1 \%$ ).

\section{Pacientes}

Se incluyeron 415 parejas (estables) en las cuales uno de los integrantes era inicialmente VIH negativo y el otro VIH-1 positivo. El integrante VIH positivo en 228 parejas fue varón, y en 187 fue mujer. A todos los seropositivos se les ofreció conocer los resultados de los test para VIH y se los estimuló en darlo a conocer a su pareja. Se les proveyó de preservativos y se los estimuló en la práctica de sexo seguro.

\section{Evaluación de factores pronósticos}

Se evaluaron múltiples variables demográficas, conducta sexual ( Nº de parejas en el año previo y uso de preservativo), historia de viajes fuera del distrito, síntomas de enfermedades de transmisión sexual (ETS) (incluyendo SIDA), circuncisión, y parámetros de laboratorio: test para VIH, ETS, y carga viral.

\section{Medición de resultado principal}

Incidencia de infección por VIH-1 por 100 personas-año y su relación con la carga viral.

\section{Resultados principales}

De las 415 parejas, 90 seroconvirtieron (22\%), con una incidencia de 11,8 por 100 personas-año. El porcentaje de transmisión de varón a mujer y viceversa no fue diferente, 12 vs. 11,6 por 100 personas-años. La incidencia fue mayor entre los 15-19 años (15,3 por 100 personas- año). Entre 137 varones no circuncidados la incidencia de contagio fue de 16,7 por 100 personas-año, mientras fue de 0 para 50 varones circuncidados. No se observó asociación significativa entre el riesgo de transmisión y el sexo, nivel educacional, conducta sexual, ETS, o viaje a otro distrito. En cambio, el riesgo de transmisión se asoció significativamente a la presencia de síntomas definidores de SIDA, flujo o disuria ( $p<0.05)$.

En el análisis multivariado* la carga viral fue el principal predictor de riesgo de transmisión, mostrando una relación dosis respuesta, es decir, a mayor carga viral, mayor riesgo de transmisión del VIH (Ver tabla).

\begin{tabular}{lcc}
\hline Carga viral en copias /ml. & $\begin{array}{c}\text { Riesgo Relativo } \\
\text { (IC 95\%) }\end{array}$ & $\begin{array}{l}\text { Incidencia aproximada de } \\
\text { infección (c/ 100 pers-año) }\end{array}$ \\
\hline$<1500$ & & 0 \\
\hline$<3500$ (grupo de referencia) & 1.0 & 2.2 \\
\hline $3500-9999$ & $5.8(2.26-17.80)$ & 12.5 \\
\hline $10.000-49.999$ & $6.91(2.96-20.15)$ & 14 \\
\hline$>50.000$ & $11.87(5.02-34.88)$ & 23 \\
\hline
\end{tabular}

(RR) Riesgo relativo de transmisión del VIH-1 según el valor de carga viral expresada.

En las parejas en las cuales hubo seroconversión la carga viral promedio fue mucho mayor que en las parejas que permanecieron discordantes (promedio 90.254 vs. 38.029 copias $/ \mathrm{ml}, \mathrm{p}=0.01$ ).

\section{Conclusiones}

Existe una fuerte asociación entre el incremento de la carga viral y el incremento del riesgo de transmisión heterosexual de VIH.

\section{COMENTARIO}

Este trabajo confirma la presumida relación entre la carga viral y el riesgo de transmisión sexual. No es fácil analizar las otras variables de este estudio debido a la gran diferencia en la idiosincrasia de la población estudiada y nuestra población. Por ejemplo, resulta difícil interpretar porque las medidas preventivas como el uso de preservativos no influyó en el riesgo de transmisión. Este estudio no solo da una respuesta, sino que abre un abanico de preguntas que aún no son respondidas: ¿determinará la carga viral el consejo con respecto a conductas sexuales en parejas discordantes estables?, ¿comenzará a ser el tratamiento antirretroviral una medida de profilaxis?, ¿deberá ser masivo el tratamiento del VIH para combatir la transmisión del virus? Hasta el momento no se puede aseverar que un paciente con carga viral indetectable no contagie, por lo tanto las recomendaciones en cuanto a sexo seguro deben ser las mismas, tampoco permite este estudio afirmar que el tratamiento con antirretrovirales disminuya el riesgo de transmisión, aunque pueda presumirse de los resultados ob- tenidos, ya que al reducir la carga viral es razonable asumir que disminuya el riesgo de transmisión. Por otro lado no debemos olvidar que la accesibilidad a estos tratamientos es limitada y que su costo impide la extensión de su uso, sin olvidar la dificultad en la adherencia al tratamiento por su complejidad, así como por el riesgo de resistencia y mutaciones. Es necesario desarrollar y evaluar métodos costo-efectivos, tales como terapias antirretrovirales o vacunas efectivas y accesibles, para la reducción de la carga viral en personas infectadas por el VIH. Sin embargo el combate de la pandemia no puede reducirse a esta única estrategia, deben desarrollarse múltiples medidas para reducir la transmisión del virus, tales como: educación, control de enfermedades de transmisión sexual, circuncisión, microbicidas tópicos, etc. Estas intervenciones no son menores si tomamos en cuenta que, por ejemplo, en el distrito en que se realizó este estudio (Rakai, Uganda) lamentablemente no se hallan disponibles las drogas antirretrovirales.

\section{*Ver glosario}

\section{Dra. Cecilia Calvo}

Unidad de Medicina Familiar y Preventiva. Hospital Italiano de Buenos Aires.

\section{Referencias}

1. Garcia PM, Kalish LA, Pittj, et al. Maternal levels of plasma human inmunodeficiency virus type 1 RNA and the risk of perinatal transmision. N Engl J Med 1999.341.394-402. 2. Musicco M, Lazzarin A Nicolosi A et al. Antiretroviral treatment of men infected with human inmunodeficiency virus type 1 reduces the incidence of heterosexual transmission. Arch Intern Med 1994;154:1971-6. 